\title{
Estimating the Prognosis of Patients With Aortic Stenosis in the Current Japanese Population
}

\author{
Kyung-Duk Min, MD, PhD
}

$\mathbf{T}$ he importance of estimating the prognosis of patients with aortic stenosis (AS) can not be emphasized too much. Today, aortic valve replacement (AVR) has been established as the standard therapy for symptomatic AS, but alternative therapies such as transcatheter aortic valve replacement (TAVR) are available for high-risk patients who are not eligible for open surgery. However, for the severest patients with a life expectancy $<1$ year or the chance of "survival with benefit" $<25 \%$ at 2 years, ${ }^{1}$ TAVR is also not recommended. Recently, to overcome this clinical discrepancy, the balloon aortic valvuloplasty has been recovered its importance as a bridge therapy to the advanced therapy such as AVR or
TAVR. Overall, the strategies for AS treatment have become more complex than ever, so the estimation of the prognosis of $\mathrm{AS}$ patients is quite important in the current clinical era.

\section{Article p1631}

To estimate the prognosis of AS in the current era, it is also essential to realize that the average age of AS patients has been getting higher as expected lifespan has been prolonged. A recent prospective population-based study demonstrated that the prevalence of AS in 50-59, 60-69, 70-79 and 80-89 year olds was $0.2,1.3,3.9$ and $9.8 \%$, respectively. ${ }^{2}$ Also, age-related

\begin{tabular}{|c|c|c|c|c|c|c|c|c|c|}
\hline \multirow{2}{*}{ Author } & \multirow{2}{*}{$\begin{array}{l}\text { Launch } \\
\text { year }\end{array}$} & \multirow{2}{*}{$\begin{array}{c}\text { No. of } \\
\text { participants }\end{array}$} & \multirow{2}{*}{ Inclusion criteria } & \multicolumn{6}{|c|}{ Survival rate (\%) } \\
\hline & & & & 1 year & 2 years & 3 years & 4 years & 5 years & Afterward \\
\hline $\begin{array}{l}\text { Frank } \\
\text { et } \mathrm{al}^{6}\end{array}$ & 1954 & 15 & AVPG $\geq 50 \mathrm{mmHg}$ or AVA $\leq 0.7 \mathrm{~cm}^{2} / \mathrm{m}^{2}$ & - & 85 & 64 & - & 48 & $\begin{array}{c}10 \\
\text { (10 years) }\end{array}$ \\
\hline $\begin{array}{l}\text { Chizner } \\
\text { et } \mathrm{al}^{7}\end{array}$ & 1966 & 42 & $\begin{array}{l}\text { AS patients ( } 32 \text { symptomatic, } \\
23 \text { moderate or severe) }\end{array}$ & 74 & 52 & 43 & - & - & - \\
\hline $\begin{array}{l}\text { Pellikka } \\
\text { et } \mathrm{al}^{8}\end{array}$ & 1984 & 622 & Asymptomatic AS, APF $\geq 4.0 \mathrm{~m} / \mathrm{s}$ & 80 & 63 & - & - & 25 & - \\
\hline Otto et $\mathrm{al}^{9}$ & 1989 & 123 & Asymptomatic AS, APF $\geq 2.5 \mathrm{~m} / \mathrm{s}$ & 93 & - & 62 & - & 26 & - \\
\hline $\begin{array}{l}\text { Bouma } \\
\text { et } \mathrm{al}^{10}\end{array}$ & 1991 & 205 & AVPG $\geq 50 \mathrm{mmHg}$ or AVA $\leq 1.0 \mathrm{~cm}^{2}$ & - & - & 49 & - & - & - \\
\hline $\begin{array}{l}\text { Rosenhek } \\
\text { et al }{ }^{11}\end{array}$ & 1994 & 126 & Asymptomatic AS, APF $\geq 4.0 \mathrm{~m} / \mathrm{s}$ & 67 & 56 & - & 33 & - & - \\
\hline $\begin{array}{l}\text { Rosenhek } \\
\text { et } \mathrm{al}^{12}\end{array}$ & 1995 & 116 & Asymptomatic AS, APF $\geq 5.0 \mathrm{~m} / \mathrm{s}$ & 64 & 36 & 25 & 12 & - & $\begin{array}{c}3 \\
\text { (6 years) }\end{array}$ \\
\hline \multirow[t]{2}{*}{$\begin{array}{l}\text { Perera } \\
\text { et } \mathrm{al}^{4}\end{array}$} & 2005 & 25 & $\begin{array}{c}\text { Asymptomatic AS, AVA } \leq 1.0 \mathrm{~cm}^{2} \text { of APF } \\
\geq 4.0 \mathrm{~m} / \mathrm{s} \text { or AVPG }>40 \mathrm{mmHg}\end{array}$ & - & - & 64 & - & - & - \\
\hline & & 41 & $\begin{array}{c}\text { Symptomatic AS, AVA } \leq 1.0 \mathrm{~cm}^{2} \text { or APF } \\
\geq 4.0 \mathrm{~m} / \mathrm{s} \text { or AVPG }>40 \mathrm{mmHg}\end{array}$ & - & - & 27 & - & - & - \\
\hline $\begin{array}{l}\text { Barasch } \\
\text { et } \mathrm{al}^{13}\end{array}$ & 2003 & 241 & AVA $<0.6 \mathrm{~cm}^{2} / \mathrm{m}^{2}$ and LVEF $>50 \%$ & 71 & - & - & - & 28 & $\begin{array}{c}12 \\
\text { (9.5 years) }\end{array}$ \\
\hline \multirow[t]{5}{*}{ Sato et $\mathrm{a}^{3}$} & 2006 & 412 & AVPG $\geq 30 \mathrm{mmHg}$ & - & - & 82 & - & - & - \\
\hline & & 154 & NYHA class I (asymptomatic) & - & - & 90 & - & - & - \\
\hline & & 208 & NYHA class II & - & - & 83 & - & - & - \\
\hline & & 47 & NYHA class III/IV & - & - & 50 & - & - & - \\
\hline & & 255 & NYHA class II/III/IV (symptomatic) & - & - & 79 & - & - & - \\
\hline
\end{tabular}

Indicated are the survival rates at indicated time points in each study. APF, aortic peak flow; AS, aortic stenosis; AVA, aortic valve area; AVPG, aortic valve peak pressure gradient; LVEF, left ventricular ejection fraction; NYHA, New York Heart Association.

The opinions expressed in this article are not necessarily those of the editors or of the Japanese Circulation Society.

Received May 23, 2015; accepted May 24, 2015; released online June 3, 2015

Department of Clinical Research and Development, and Cell Biology, National Cerebral and Cardiovascular Center, Suita, Japan

Mailing address: Kyung-Duk Min, MD, PhD, Department of Clinical Research and Development, and Cell Biology, National Cerebral and

Cardiovascular Center, 5-7-1 Fujishirodai, Suita 565-8565, Japan. E-mail: address min@ ncvc.go.jp

ISSN-1346-9843 doi:10.1253/circj.CJ-15-0578

All rights are reserved to the Japanese Circulation Society. For permissions, please e-mail: cj@j-circ.or.jp 
comorbidities are increasing and having a significant effect on the prognosis of AS patients. Thus, in the advanced aging society that we are facing in Japan today, the natural history of AS patients will differ from previous reports in other countries.

In this issue of the Journal, Sato et $\mathrm{al}^{3}$ report the prognosis of Japanese AS patients as well as proposing an original risk score to estimate the prognosis of AS patients. The authors enrolled 412 patients with AS, which was defined as aortic valve peak pressure gradient (AVPG) $>30 \mathrm{mmHg}$, from their CHART-2 study. After their follow-up for 3-years, the overall mortality rate was $17.7 \%$ (73 events). Crude 3-year mortality was $9.5 \%, 16.5 \%$ and $49.7 \%$ for patients with NYHA class I, II, and III/IV, respectively. Furthermore, from their stepwise Cox regression analysis, the authors identified 7 factors and proposed a novel risk score to estimate the prognosis by summing up the weighted score of each factor: NYHA class III/IV (score 6), male sex (3), serum albumin level $\leq 4 \mathrm{~g} / \mathrm{dl}$ (2), aortic peak flow $(\mathrm{APF}) \geq 4.5 \mathrm{~m} / \mathrm{s}$ (2), age $\geq 75$ years, chronic kidney disease (2) and anemia (1). Each case was assigned to a low(sum of the scores 0-6), intermediate- (7-10) or high-risk (11-18) group. Compared with the low-risk group, the hazard ratios of the intermediate- and high-risk groups were significantly higher for all-cause mortality (HR 4.49, 95\% confidence interval (CI) 2.23-8.43, P<0.01; HR 18.34, 95\% CI 9.18-36.63, $\mathrm{P}<0.01$, respectively) and it was also the case for cardiovascular death and non-cardiovascular death.

One of the most important facts provided here is the natural history of AS in the current Japanese population. The prognosis of AS demonstrated in previous papers has varied widely (Table). Even the study designs were different, the prognosis of AS tends to be better in the recent studies. The 2-year event-free survival in asymptomatic patients was $63 \%$ and $56 \%$ in the studies conducted in 1984 and 1994, respectively, but lower than 3-year event-free survival in 2005 (64\%). This was mainly achieved by advancements in medical care through the decades. Also, it should be taken into account that the mortality of AS patients will vary among the cohorts. In Table, the 3-year survival of symptomatic AS shown by Sato et al is as high as $79 \%,{ }^{3}$ whereas that by Perera et al is $27 \%{ }^{4}$ (note that the majority of the patients become symptomatic when the disease becomes severe eg, APF $\geq 4.0 \mathrm{~m} / \mathrm{s}$ ). It indicates that mortality of AS patients might be higher in Japan compared with previous reports.

Another feature of the present study is the original risk stratification score using comorbidities. In an aged society, the comorbidities of patients directly affect the outcome. Indeed, Martinez-Selles et al recently reported that the average Charlson comorbidity index was $3.0 \pm 1.7$ in patients with severe AS aged over 80 and that $16.3 \%$ of them showed high comorbidity (index $\geq 5$ ). ${ }^{5}$ They also described the Charlson index as an independent predictor of prognosis. Additionally, the planned medical intervention was not associated with prognosis in patients with high comorbidity, which is clearly indicating that the estimation of prognosis is never accurate without consideration of the comorbidities in AS patients. In the present paper, Sato et al successfully identify 7 comorbidities and weight them to generate their original risk score.

The present report may have a substantial effect on the care of AS patients. In daily practice, the prognosis of each AS patient could be estimated from his/her individual clinical data, which may strongly support objective decision making by patients, especially whether or not to undergo invasive interventions.

Then, what comes next to improve more? As the participants of the present study were recruited from the CHART-2 study, the available comorbidity data were limited. The major life-limiting comorbidities, such as cancer, stroke, respiratory disorders etc., might have been missed. In addition, information about congenital abnormalities (uni- and bicuspid valve) and possible risks for progression of AS such as diabetes or a history of smoking may have a potential contributory effect on the accuracy of the risk score. Finally, just as the present study revealed, the natural course of AS does change according to the population, era and sociomedical factors. Continuous updates of objective study and appropriate application to clinical decision-making in the real world are the keys to best practice for AS.

\section{References}

1. Nishimura RA, Otto CM, Bonow RO, Carabello BA, Erwin JP 3rd, Guyton RA, et al. 2014 AHA/ACC guideline for the management of patients with valvular heart disease: A report of the American College of Cardiology/American Heart Association Task Force on Practice Guidelines. J Am Coll Cardiol 2014; 63: e57-e185, doi: 10.1016/j.jacc.2014.02.536.

2. Eveborn GW, Schirmer H, Heggelund G, Lunde P, Rasmussen K. The evolving epidemiology of valvular aortic stenosis: The tromso study. Heart 2013; 99: 396-400.

3. Sato K, Sakata Y, Miura M, Tadaki S, Ushigome R, Yamauchi T, et $\mathrm{al}$; on behalf of the CHART-2 Investigators. Comprehensive risk stratification of Japanese patients with aortic stenosis: A proposal of a new risk score from the CHART-2 Study. Circ J 2015; 79: 1631 1638.

4. Perera S, Wijesinghe N, Ly E, Devlin G, Pasupati S. Outcomes of patients with untreated severe aortic stenosis in real-world practice. NZ Med J 2011; 124: 40-48.

5. Martinez-Selles M, Diez-Villanueva P, Sanchez-Sendin D, Carro Hevia A, Gomez Doblas JJ, Garcia de la Villa B, et al. Comorbidity and intervention in octogenarians with severe symptomatic aortic stenosis. Int J Cardiol 2015; 189: 61 -66.

6. Frank S, Johnson A, Ross J Jr. Natural history of valvular aortic stenosis. Br Heart J 1973; 35: 41 - 46.

7. Chizner MA, Pearle DL, deLeon AC Jr. The natural history of aortic stenosis in adults. Am Heart J 1980; 99: 419-424.

8. Pellikka PA, Sarano ME, Nishimura RA, Malouf JF, Bailey KR, Scott CG, et al. Outcome of 622 adults with asymptomatic, hemodynamically significant aortic stenosis during prolonged follow-up. Circulation 2005; 111: 3290-3295.

9. Otto CM, Burwash IG, Legget ME, Munt BI, Fujioka M, Healy NL, et al. Prospective study of asymptomatic valvular aortic stenosis: Clinical, echocardiographic, and exercise predictors of outcome. Circulation 1997; 95: 2262-2270.

10. Bouma BJ, van Den Brink RB, van Der Meulen JH, Verheul HA, Cheriex EC, Hamer HP, et al. To operate or not on elderly patients with aortic stenosis: The decision and its consequences. Heart 1999; 82: $143-148$.

11. Rosenhek R, Binder T, Porenta G, Lang I, Christ G, Schemper M, et al. Predictors of outcome in severe, asymptomatic aortic stenosis. $N$ Engl J Med 2000; 343: 611-617.

12. Rosenhek R, Zilberszac R, Schemper M, Czerny M, Mundigler G, Graf S, et al. Natural history of very severe aortic stenosis. Circulation 2010; 121: 151-156.

13. Barasch E, Petillo F, Pollack S, Rhee PD, Stovold W, Reichek N. Clinical and echocardiographic correlates of mortality in medically treated patients with severe isolated aortic stenosis and normal left ventricular ejection fraction. Circ J 2014; 78: 232-239. 